\author{
WojCIECH DyBA \\ Uniwersytet im. Adama Mickiewicza w Poznaniu, Polska \\ Adam Mickiewicz University in Poznań, Poland
}

\title{
Klastry meblarskie na tle struktury przestrzennej przemystu meblarskiego w Polsce
}

\section{Furniture Clusters in the Spatial Structure of the Furniture Industry in Poland}

Streszczenie: Przemysł meblarski to ważna gałąź polskiej gospodarki, a meble w 2016 roku były jednym z trzech głównych produktów eksportowanych z Polski (obok samochodów i komponentów branży motoryzacyjnej oraz artykułów spożywczych). Celem artykułu jest przedstawienie wyników badań nad strukturą przestrzenną przemysłu meblarskiego w Polsce, ze szczególnym uwzględnieniem klastrów. Klastry rozumiane są dwojako: jako przestrzenne skupienia (koncentracje) firm meblarskich i zatrudnienia w meblarstwie, jak również jako sformalizowane porozumienia: inicjatywy i organizacje klastrowe zrzeszające podmioty branży meblarskiej na pewnym obszarze. Analizę przeprowadzono z wykorzystaniem zarówno metod wskaźnikowych (iloraz lokalizacji, wskaźnik koncentracji Florence’a), jak i metod klasycznie stosowanych w geografii ekonomicznej oraz metod ekonometrii przestrzennej - lokalnych związków przestrzennych stanowiących terytorialne rozwinięcie tzw. autokorelacji przestrzennej. Wyniki badania wskazują ponadprzeciętną - w stosunku do innych branż przemysłu - koncentrację przestrzenną przemysłu meblarskiego w Polsce: na poziomie regionalnym i subregionalnym (powiatowym, np. w południowej i środkowej Wielkopolsce oraz w zachodniej części województwa warmińsko-mazurskiego). Inicjatywy i organizacje klastrowe są rozmieszczone na terenie siedmiu województw, nie tylko na tych obszarach, w których występują klastry - skupienia firm meblarskich. Szczegółowa analiza zrzeszonych w nich przedsiębiorstw oraz ich funkcjonowania pozwala jednak stwierdzić, że jakkolwiek zatrudnienie w trzech największych klastrach stanowi ok. 20\% zatrudnienia w kraju, w meblarskich inicjatywach i organizacjach klastrowych zrzeszonych jest mniej niż 1\% firm obejmujących niespełna 1\% wszystkich osób zatrudnionych w meblarstwie w Polsce.

\begin{abstract}
Furniture industry is an important branch of Polish economy. Furniture in 2016 is third in the ranking of products exported from Poland (with the first and second position occupied by cars and automobile parts, and consumables). The aim of the article is to present the results of a study devoted to the spatial structure of furniture industry in Poland and a place and role of clusters in this structure. Clusters are understood twofold: as spatial concentrations of furniture companies and employment in furniture, but also as formalised cooperation agreements - furniture cluster initiatives and organisations located in certain areas. The analysis was conducted with the use of indicator methods (location quotient, Florence's concentration indicator) commonly used in economic geography, but also methods of spatial econometrics - local spatial associations being a territorial extension of spatial autocorrelation. The study showed the above average (as compared to other branches) spatial concentration of furniture industry in Poland: on the regional (voivodeships) and subregional (poviat) level, for example in the southern and central Wielkopolska and the western part of Warmia-Mazury. Cluster initiatives and organisations are located in seven regions, not only in the
\end{abstract}


areas where spatial concentrations of furniture companies are present. The study showed that three biggest clusters of furniture employed $20 \%$ of all employees of this branch and were important in the structure of furniture industry in Poland. However, less than 1\% of furniture companies, employing less than 1\% of furniture employees are actually associated in cluster initiatives and organisations.

Słowa kluczowe: analiza klastrów; autokorelacja przestrzenna; iloraz lokalizacji; klastry; lokalne zależności przestrzenne

Keywords: cluster analysis; clusters; local spatial associations; location quotient; spatial autocorrelation

Otrzymano: 18 grudnia 2016

Received: 18 December 2016

Zaakceptowano: 11 lutego 2017

Accepted: 11 February 2017

Sugerowana cytacja / Suggested citation:

Dyba, W. (2017). Klastry meblarskie na tle struktury przestrzennej przemysłu meblarskiego w Polsce. Prace Komisji Geografii Przemysłu Polskiego Towarzystwa Geograficznego, 31(1), 38-51.

\section{WSTĘP}

Klastry to popularna koncepcja badawcza w geografii ekonomicznej opisująca zjawisko przestrzennego skupiania się firm oraz instytucji jednej branży gospodarczej oraz tworzenia pomiędzy nimi relacji. Od momentu wprowadzenia tego pojęcia w latach dziewięćdziesiątych przez M.E. Portera (1990) koncepcja ta stała się przedmiotem licznych badań zarówno teoretycznych, jak i empirycznych (przegląd zagranicznych badań nad klastrami, wykonany z zastosowaniem metody bibliometrycznej, znajduje się $\mathrm{w}$ artykule: S.C.S. Cruz, A.A.C. Teixeira, 2010).

Jedną z silnych branż polskiej gospodarki, w której przedsiębiorstwa mają tendencję do koncentracji w przestrzeni, jest meblarstwo (Jędrysiak, Piwoni-Krzeszowska, 2012; Ratajczak-Mrozek, Herbeć, 2013). Przykłady klastrów meblarskich w wybranych regionach w Polsce stanowiły przedmiot zarówno badań naukowych, jak i opracowań o charakterze strategii branżowych w województwach: wielkopolskim (Gorynia, Jankowska, Owczarzak, 2007; Kalupa, 2007), zachodniopomorskim (Szultka, Koszarek, Piwowarczyk, 2005; Kapuściński, Koszarek, Listwoń, Szultka, 2007), warmińsko-mazurskim (Mackiewicz, Kwiatkowski, Sętorek, 2015), a także w konkretnym, swarzędzkim klastrze meblowym (Stryjakiewicz, 1999; Dyba, Stryjakiewicz, 2014). W badaniu zaprezentowanym w niniejszym artykule przeprowadzono analizę rozmieszczenia klastrów sektora meblarskiego w całej Polsce. Klastry rozumiane są dwojako: jako przestrzenne skupienia firm meblarskich i zatrudnienia w meblarstwie oraz jako sformalizowane porozumienia: inicjatywy i organizacje zrzeszające firmy i instytucje branży meblarskiej na pewnym obszarze i tworzące możliwości współpracy między nimi.

Badaniu przyświecały dwa podstawowe cele: metodologiczny i poznawczy. Cel metodologiczny obejmował identyfikację klastrów w przemyśle meblarskim w Polsce metodami statystycznymi i ekonometrycznymi. Obszary koncentracji (skupienia) firm meblarskich i zatrudnienia w meblarstwie wyznaczono na podstawie bazy danych wszystkich firm produkujących meble, m.in. przy pomocy niewykorzystywanej dotychczas $\mathrm{w}$ tym kontekście metody lokalnych zależności przestrzennych, będącej przestrzennym rozwinięciem metody autokorelacji przestrzennej. Cel poznawczy obejmował analizę znaczenia przemysłu meblarskiego w gospodarce Polski (produkcji sprzedanej i eksporcie), a także identyfikację sformalizowanych, meblarskich inicjatyw 
i organizacji klastrowych, w których pod wspólną nazwą odwołującą się do koncepcji klastra, zachodzi kooperacja pomiędzy podmiotami branży meblarskiej. Cel ten został osiągnięty przy użyciu danych wtórnych: publikacji, stron internetowych. Następnie porównano, w jakim stopniu klastry - przestrzenne skupienia firm meblarskich, pokrywają się z miejscami, w których zawiązano współpracę podmiotów meblarskich.

\section{METODY IDENTYFIKACJI KLASTRÓW}

Tematyka klastrowa podejmowana jest w Polsce w licznych pracach naukowych i badaniach (Brodzicki, Szultka, 2002; Gorynia, Jankowska, 2008; Skawińska, Zalewski, 2009; Kowalski, 2013). Jest to także jedno z narzędzi polityki innowacyjnej, szczególnie na poziomie regionalnym (ostatnio w kontekście tzw. inteligentnych specjalizacji). Definicja klastra sformułowana przez Portera jest jednak niejednoznaczna, co spotkało się z krytyką części środowiska naukowego (Martin, Sunley, 2003), a także wprowadziło w literaturze naukowej oraz dokumentach polityki regionalnej wiele nieścisłości terminologicznych. Przegląd literatury i dokumentów dotyczących problematyki klastrów pozwala na wyznaczenie ich trzech podstawowych rodzajów ze względu na stopień sformalizowania (Dyba, 2016a):

- klastry - przestrzennie skoncentrowane skupienia przedsiębiorstw i instytucji w pewnej branży gospodarczej,

- inicjatywy klastrowe - sformalizowane działania podejmowane na rzecz współpracy przestrzennie skoncentrowanych podmiotów (firm i instytucji otoczenia biznesu) w pewnej branży gospodarczej,

- organizacje klastrowe - instytucje koordynujące współpracę grupy przedsiębiorstw i instytucji z pewnej branży gospodarczej, zarejestrowane do pełnienia tej funkcji lub posiadające osobowość prawną.

Podstawowymi warunkami istnienia klastra w pewnej branży jest koncentracja przestrzenna pewnej znaczącej liczby firm tej branży na jakimś obszarze, a także relacje i powiązania pomiędzy tymi firmami oraz firmami i instytucjami, organizacjami, stowarzyszeniami w otoczeniu, niekiedy o sformalizowanym charakterze (Porter, 1990; Gorynia, Jankowska, 2008; Skawińska, Zalewski, 2009). Dotychczasowe publikacje naukowe w Polsce brały pod uwagę najczęściej tylko jeden z tych warunków, uznając, że klastrami są skupienia przestrzenne firm wybranych branż lub wszystkie działania i instytucje odwołujące się do koncepcji klastra. W niniejszym artykule podjęta zostaje próba połączenia obu warunków dla przemysłu meblarskiego.

Tradycyjnie do określania koncentracji przestrzennej przemysłu w badaniach geograficznych stosuje się współczynnik lokalizacji, zwany również wskaźnikiem koncentracji Florence'a (ang. Coefficient of Localisation, F) oraz iloraz lokalizacji (ang. Location quotient, LQ), w literaturze zwany także wykładnikiem lokalizacji. Współczynnik lokalizacji określa koncentrację badanego zjawiska we wszystkich badanych jednostkach (np. dla całego kraju). Iloraz lokalizacji jest sposobem pomiaru względnej nadwyżki lub niedoboru w występowaniu zjawiska $\mathrm{w}$ jednostce na tle całego zjawiska w kraju, w stosunku do wielkości bazowej (np. nadwyżki firm meblarskich w jednostce przestrzennej w stosunku do wszystkich firm $w$ tej jednostce, ponadprzeciętnego zatrudnienia w meblarstwie w stosunku do całkowitego zatrudnienia w tej jednostce). Miary te są opisane w klasycznych podręcznikach geografii gospodarczej i regionalnej (Isard, 1965; Fajferek, 1966; Troc, 1991; za: Czapliński, Rachwał, Tobolska, Uliszak, 2013) i często wykorzystywane 
Tab. 1. Metody badań koncentracji przestrzennej przemysłu - porównanie

\begin{tabular}{|c|c|c|}
\hline & Metody statystyczne - wskaźnikowe & $\begin{array}{l}\text { Metody ekonometrii przestrzennej oparte na } \\
\text { autokorelacji przestrzennej }\end{array}$ \\
\hline \multirow{3}{*}{$\begin{array}{l}\text { Miary } \\
\text { globalne }\end{array}$} & $\begin{array}{l}\text { Współczynnik lokalizacji } \\
\text { (wskaźnik koncentracji Florence’a) }\end{array}$ & $\begin{array}{l}\text { Globalna statystyka autokorelacji } \\
\text { przestrzennej I Morana }\end{array}$ \\
\hline & $\begin{array}{l}\qquad F=\frac{\sum_{i=1}^{n} \mid \text { Wir }-\mathrm{Wi} \mid}{200} \\
\mathrm{~W}_{\mathrm{ir}} \text { - procentowy udział jednostki } \\
\text { przestrzennej i w wybranej wielkości } \\
\text { przemysłu r w kraju (liczba firm meblarskich, } \\
\text { zatrudnienie w meblarstwie) } \\
\text { W }_{\mathrm{i}} \text { - procentowy udział tejże jednostki } \\
\text { przestrzennej w wielkości przyjętej za bazową } \\
\text { (np. liczba firm ogółem, liczba ludności) }\end{array}$ & $\begin{array}{l}\quad I=\frac{n}{s_{0}} \cdot \frac{\sum_{i=1}^{n} \sum_{j=1}^{n} c_{i j}\left(x_{i}-\bar{x}\right)\left(x_{j}-\bar{x}\right)}{\sum_{i=1}^{n}\left(x_{1}-\bar{x}\right)^{2}} \\
n \text { - liczba jednostek przestrzennych } \\
c_{i j} \text { - elementy macierzy bezpośredniego } \\
\text { sąsiedztwa } C \\
S_{0} \text { - suma elementów macierzy } C \\
x_{i} \text { - jednostki obserwacji }\end{array}$ \\
\hline & $\begin{array}{l}\text { Interpretacja: } 0 \leq \mathrm{F} \leq 1 \\
\text { Im bliżej } 1 \text {, tym większa koncentracja, im } \\
\text { bliżej } 0 \text {, tym większe rozproszenie, dyspersja: } \\
\text { procentowe rozmieszczenie przemysłu we } \\
\text { wszystkich jednostkach tak samo jak wartość } \\
\text { podstawowa }\end{array}$ & $\begin{array}{l}\text { Interpretacja: } \\
I>[-1 /(n-1)]-\text { dodatnia autokorelacja } \\
\text { przestrzenna } \\
I<[-1 /(n-1)]-\text { ujemna autokorelacja } \\
\text { przestrzenna } \\
I=[-1 /(n-1)]-\text { losowy rozkład przestrzenny }\end{array}$ \\
\hline \multirow{3}{*}{$\begin{array}{l}\text { Miary } \\
\text { lokalne }\end{array}$} & Iloraz lokalizacji & Lokalne związki przestrzenne \\
\hline & $\begin{array}{l}\qquad L Q=\frac{W i r}{W i} \\
\mathrm{~W}_{\text {ir }} \text { - procentowy udział jednostki } \\
\text { przestrzennej i w wybranej wielkości } \\
\text { przemysłu r w kraju } \\
\mathrm{W}_{\mathrm{i}} \text { - procentowy udział tejże jednostki } \\
\text { przestrzennej w wielkości przyjętej za bazową }\end{array}$ & $\begin{array}{l}\qquad I=z_{i} \sum_{j=1}^{n} w_{i j} z_{j} \\
Z_{i}, Z_{j} \text { - odchylenia od średniej } \\
w_{i j}-\text { standaryzowane macierze } \\
\text { bezpośredniego sąsiedztwa C, obliczane } \\
\text { według formuły } w_{i j}=c_{i j} / \sum c_{i j}\end{array}$ \\
\hline & $\begin{array}{l}\text { Interpretacja: } \\
\text { LQ = } 1 \text { - proporcjonalność rozmieszczenia } \\
\text { przemysłu w danej jednostce przestrzennej } \\
\text { w stosunku do wartości przyjętej za bazową } \\
\text { LQ >1 - nadproporcjonalność rozmieszczenia } \\
\text { przemysłu, „nadmiar” w jednostce } \\
\text { LQ < } 1 \text { - stosunkowy „niedobór” w jednostce }\end{array}$ & $\begin{array}{l}\text { Skupienia mogą przyjmować układ: } \\
\text { high-high (HH) - jednostek o wysokich } \\
\text { wartościach badanej cechy, otoczonych przez } \\
\text { jednostki o również wysokich wartościach } \\
\text { low-low (LL) - jednostek o niskich } \\
\text { wartościach otoczonych przez podobnych } \\
\text { sąsiadów } \\
\text { high-low (HL) i low-high (LH) - jednostek } \\
\text { wyraźnie odróżniających się od otoczenia }\end{array}$ \\
\hline
\end{tabular}

Źródło: opracowanie własne na podstawie Czapliński i in. (2013) oraz Kossowski (2009)

w badaniach przestrzennych przemysłu w Polsce (Stryjakiewicz, 1999; Rachwał, 2010). Iloraz lokalizacji był również wykorzystywany jako metoda identyfikacji potencjalnych klastrów w Polsce (Kowalski, 2013; Brodzicki, Kuczewska, 2013).

Innym niewykorzystywanym dotychczas sposobem wyznaczania klastrów - obszarów koncentracji przestrzennej zjawisk - są metody ekonometrii przestrzennej oparte na autokorelacji przestrzennej, cechujące się tym, że uwzględniają zależności przestrzenne (przestrzenne zależności funkcyjne) pomiędzy jednostką a innymi jednostkami. W metodach tych do obliczeń włącza się macierze sąsiedztwa między jednostkami ${ }^{1}$. Współczynnik I Morana to miara globalna, w syntetyczny sposób charakteryzująca autokorelację przestrzenną, a zatem korelację pomiędzy wartościami

${ }^{1}$ Wybrane metody ekonometryczne oraz elementy modelowania przestrzennego do wyznaczania klastrów - przestrzennych skupień firm w wybranych branżach zastosowane zostały w pracy: Brodzicki, Kuczewska (2013). 
obserwacji jednej zmiennej w jednostce terytorialnej w stosunku do obszarów bezpośrednio ją otaczających (pozwala stwierdzić, czy zależność przestrzenna występuje pomiędzy wszystkimi jednostkami i jak jest silna) (Cliff, Ord, 1973; za: Suchecki 2010). Lokalne związki przestrzenne I Morana (Local Indicators of Spatial Association - LISA) pozwalają określić dla każdej jednostki lokalne odchylenia od globalnego wzorca autokorelacji przestrzennej, poprzez wyznaczenie podobieństwa jednostki do jej sąsiadów. W wyniku zastosowania analizy LISA możliwe jest sprawdzenie, czy dana jednostka jest otoczona przez inne jednostki o podobnych albo różnych wartościach zmiennej w stosunku do losowego rozmieszczenia tych wartości w przestrzeni (Anselin, 1988; 1995; za: Kopczewska, 2006; Kossowski, 2009). Porównanie metod badań koncentracji przestrzennej przemysłu znajduje się w tab. 1.

W prezentowanych w niniejszym artykule badaniach lokalne statystyki I Morana pozwoliły zidentyfikować efekty aglomeracyjne - skupienia podobnych wartości w zakresie liczby firm meblarskich i zatrudnienia w meblarstwie w Polsce ${ }^{2}$. Za klastry - określane również jako tzw. hot spoty (ang. hot spots) - uznano układy wysokie-wysokie (ang. high-high), czyli obszary wysokich wartości liczby firm meblarskich i zatrudnienia w meblarstwie, otoczone przez obszary o równie wysokich wartościach tych zmiennych.

\section{PRZEMYSŁ MEBLARSKI W POLSCE W LATACH 2005-2015}

Od końca lat dziewięćdziesiątych, a zwłaszcza po wstąpieniu do Unii Europejskiej, następuje w Polsce systematyczny wzrost produkcji sprzedanej przemysłu meblarskiego. W 2015 roku wartość produkcji sprzedanej wyniosła 39,1 mld zł. Średnioroczne tempo wzrostu tego przemysłu w latach 2005-2015 wyniosło 6,1\%, a w latach 2012-2015 (po niewielkim spowolnieniu spowodowanym ogólnoświatowym kryzysem gospodarczym) - 10,7\% (przy wartości 2,3\% dla całego przetwórstwa przemysłowego, ryc. 1).

Rozwój produkcji mebli w ostatnich latach pozwolił polskiej branży meblarskiej na awans na pozycję szóstego największego producenta mebli na świecie i umocnienie się na trzecim miejscu wśród europejskich gospodarek (pierwsza piątka to Chiny, USA, Niemcy, Włochy i Indie).

W latach 2005-2015 systematycznie rósł też eksport mebli (ryc. 2). W 2015 roku w stosunku do roku poprzedniego eksport wzrósł o 8\% do rekordowego poziomu 8,6 mld euro wyeksportowanych mebli. Saldo bilansu handlowego wyniosło 7,1 mld euro i wśród branż przetwórstwa przemysłowego ustępowało jedynie przemysłowi motoryzacyjnemu (saldo 7,4 mld euro) i spożywczemu (saldo 7,3 mld).

Dane z pierwszych trzech kwartałów 2016 roku potwierdzają kontynuację trendu wzrostowego w zakresie wielkości produkcji sprzedanej meblarstwa i eksportu mebli. Ponadto, jak wskazują raporty branżowe (Polskie meble..., 2016), wysoka i wzrostowa jest w produkcji mebli rentowność netto - w 2015 roku na poziomie 5,8\%, a także rentowność kapitału (ROE) - w 2015 r. 16,2\% (średnia dla przetwórstwa przemysłowego to $12,2 \%$ ).

\footnotetext{
${ }^{2} \mathrm{~W}$ publikacjach z zakresu ekonometrii przestrzennej wszystkie te typy aglomeracji określane są jako klastry, np. „klastry niskich wartości cechy/zjawiska” lub „klastry wysokich wartości cechy/zjawiska”. Osobno wyróżnia się tzw. outliersów - obszary o wysokiej wartości badanej zmiennej, otoczone przez obszary o niskich wartościach zmiennej lub na odwrót.
} 
Ryc. 1. Wartość produkcji sprzedanej przemysłu meblarskiego w Polsce w latach 2005-2015 (w mld zł)

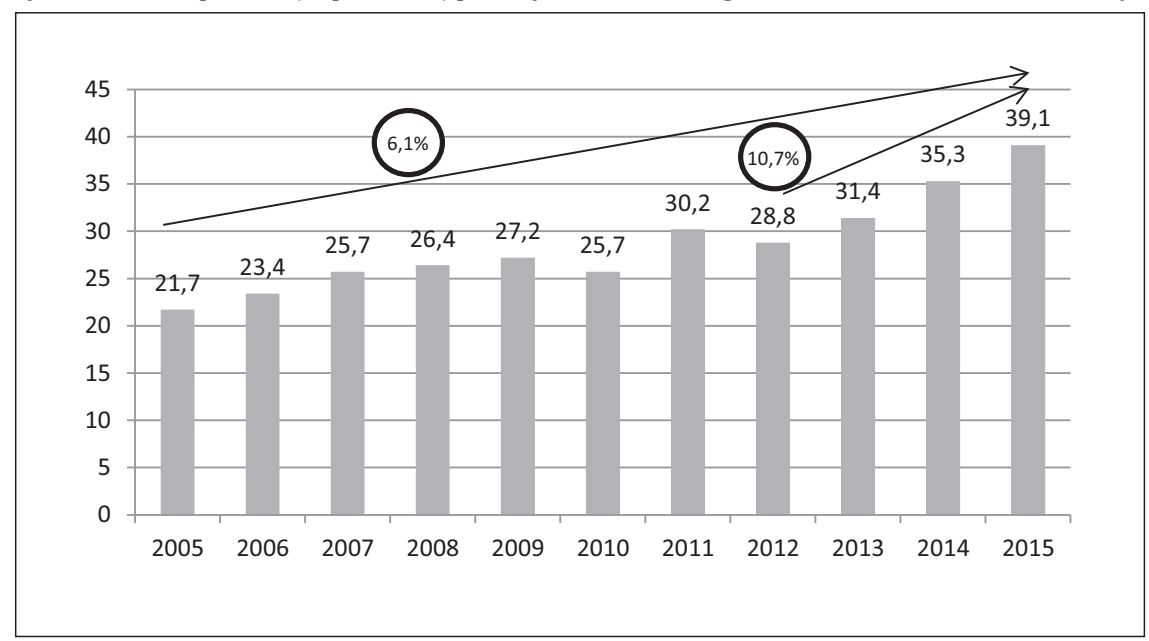

* Średnioroczne tempo wzrostu

Źródło: opracowanie własne na podstawie danych GUS

Ryc. 2. Handel zagraniczny meblami w Polsce w latach 2005-2015 (w mld euro)

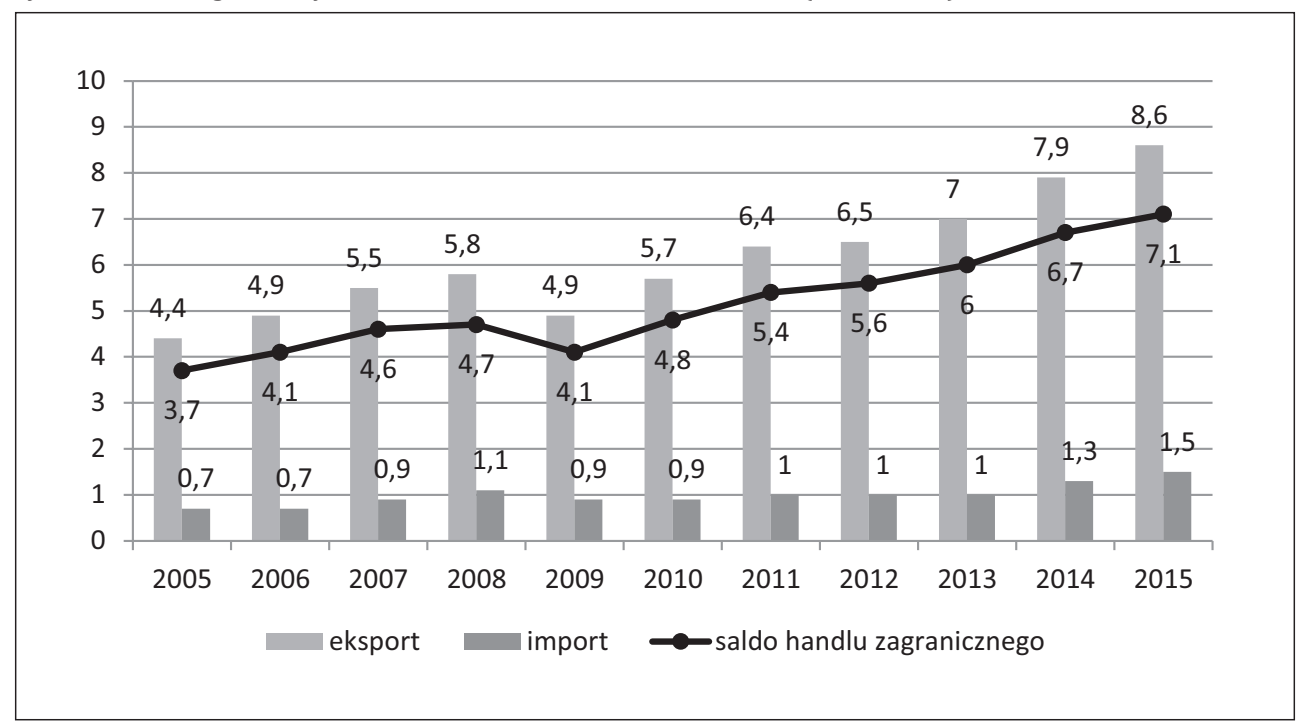

Źródło: opracowanie własne na podstawie danych Eurostatu

Europejskie Obserwatorium Klastrów (www.clusterobservatory.com) wskazywało w 2011 roku (ostatni rok, dla którego instytut zebrał dane), że - jakkolwiek Polska należy do europejskiej czołówki w zakresie liczby firm meblarskich i zatrudnienia w meblarstwie (ryc. 3), a niektóre polskie regiony (wielkopolski, warmińsko-mazurski) cechują się dużą liczbą firm meblarskich w strukturze firm ogółem - kraj cechuje się brakiem organizacji klastrowych, czyli instytucji wpierających współpracę firm meblarskich (które występowały m.in. w północnych Włoszech, południowej Hiszpanii czy północnej Austrii). 
Ryc. 3. Zatrudnienie w sektorze meblarstwa w krajach europejskich w 2011 roku (zaznaczono pięć krajów o największym zatrudnieniu)

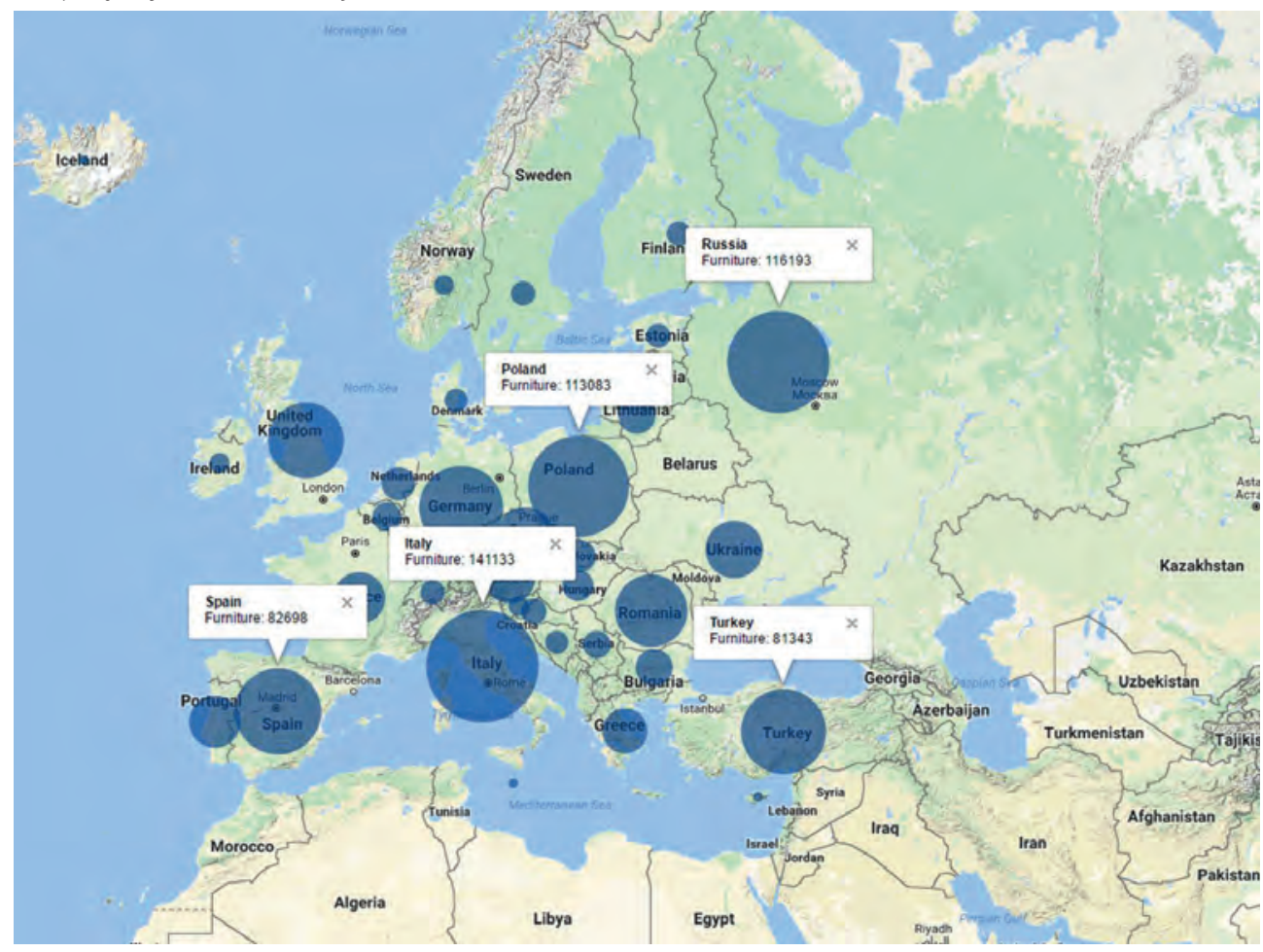

Źródło: www.clusterobservatory.eu

Poniżej zidentyfikowane są zasięgi klastrów meblarskich w Polsce (obszarów koncentracji firm meblarskich i zatrudnienia w przemyśle meblarskim) oraz lokalizacje meblarskich porozumień klastrowych zawiązanych w latach 2011-2016.

\section{KLASTRY MEBLARSKIE W POLSCE - PRZEBIEG I WYNIKI BADAŃ STATYSTYCZNYCH I EKONOMETRYCZNYCH}

Do analizy wykorzystana została baza danych wszystkich firm meblarskich w Polsce wpisanych w rejestr REGON do działów 31.01, 31.02 i 31.09 PKD 2007 (według stanu na 30 września 2016 roku). Baza ta została zakupiona od firmy Emmy B2B z Gdańska i zawierała dane o 27168 firmach meblarskich, zatrudniających 186616 osób. 137 firm $(0,5 \%)$ to podmioty duże, zatrudniające 250 osób i więcej, 529 firm $(1,95 \%)$ to firmy średnie, zatrudniające od 50 do 250 osób, 1808 (6,65\%) to podmioty małe, zatrudniające od 10 do 50 pracowników, a 24694 (90,89\%) to firmy mikro, w których pracuje od 1 do 9 osób $^{3}$. Klastry firm produkujących meble w Polsce wyznaczano na podstawie

${ }^{3}$ Zaznaczyć należy, że statystyki dotyczące liczby firm i zatrudnienia mogą być nieco zawyżone. Wynika to z tego, że często właściciele podmiotów (szczególnie mikroprzedsiębiorstwa) nie wyrejestrowują ich z rejestru REGON, mimo że działalność nie jest już prowadzona. Ponadto dane o zatrudnieniu pochodzą z różnych lat i niekiedy są szacunkowe - gdyż firmy nie przekazują pełnych informacji na ten temat do żadnej instytucji lub centralnej bazy. Według danych Ogólnopolskiej Izby Gospodarczej Producentów Mebli 
liczby firm oraz zatrudnienia na poziomie regionalnym (w województwach) i subregionalnym (w powiatach).

W pierwszym etapie dokonana została analiza koncentracji przestrzennej przemysłu meblarskiego miarami globalnymi. Wyniki - przestawione w tab. 2 świadczą o niemałej koncentracji firm meblarskich i ponadprzeciętnej koncentracji zatrudnienia w meblarstwie w kraju. Dla porównania T. Rachwał (2010) obliczył, że współczynnik lokalizacji dla zatrudnienia w przemyśle w województwach w Polsce w 2007 roku wyniósł 0,208 (a brano pod uwagę również szczególnie nadproporcjonalne zatrudnienie w przemyśle w województwie śląskim).

Tab. 2. Koncentracja przestrzenna przemysłu meblarskiego w regionach i subregionach w Polsce w 2016 roku

\begin{tabular}{|l|l|c|c|}
\hline Wskaźnik & \multicolumn{1}{|c|}{ Przedmiot } & $\begin{array}{c}\text { Poziom regionalny } \\
\text { (województwa) }\end{array}$ & Poziom subregionalny (powiaty) \\
\hline \multirow{2}{*}{ F } & Liczba firm & 0,105 & 0,255 \\
\cline { 2 - 4 } & Zatrudnienie & 0,267 & 0,465 \\
\hline \multirow{2}{*}{ I Moran } & Liczba firm & - & $0,229(0,195$ dla LQ1) \\
\cline { 2 - 4 } & Zatrudnienie & - & $0,247(0,241$ dla LQ2) \\
\hline
\end{tabular}

Wyjaśnienie: na poziomie regionalnym województw nie wyliczono globalnej statystyki I Morana ze względu na zbyt małą liczbę jednostek.

Źródło: opracowanie własne

Wyniki badania koncentracji przestrzennej meblarstwa na poziomie regionalnym - wojewódzkim - przedstawione są na ryc. 4 i 5.

Najwyższe ilorazy lokalizacji w liczbie firm meblarskich w regionach (LQ1) w odniesieniu do liczby firm ogółem wystąpiły w województwach: małopolskim $(1,43)$, podkarpackim $(1,41)$ i wielkopolskim $(1,39)$. W zakresie zatrudnienia w meblarstwie

Ryc. 4-5. Iloraz lokalizacji liczby firm (LQ1) i zatrudnienia (LQ2) w meblarstwie w województwach w Polsce

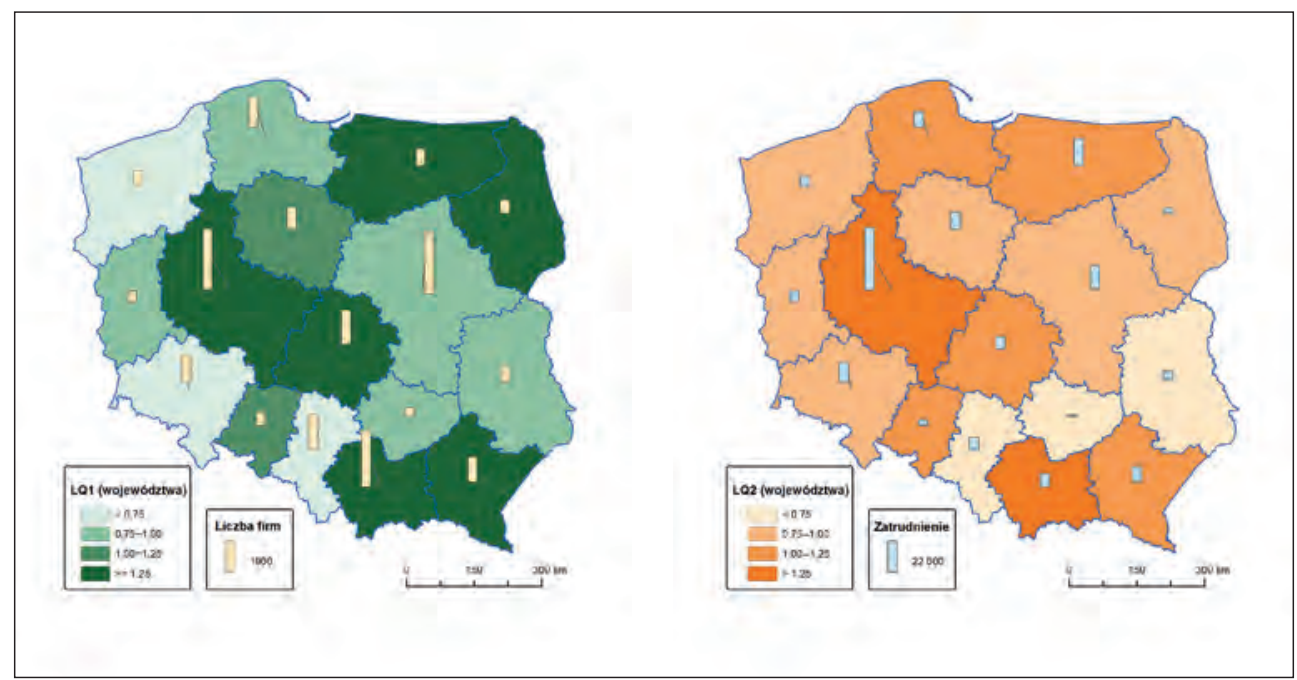

Źródło: opracowanie własne

(www.oigpm.org.pl), w trzecim kwartale 2016 roku na rynku funkcjonowało ok. 26600 przedsiębiorstw zatrudniających ok. 130000 osób. 
Ryc. 6-7. Klastry przemysłu meblarskiego wyznaczone metodą ilorazu lokalizacji

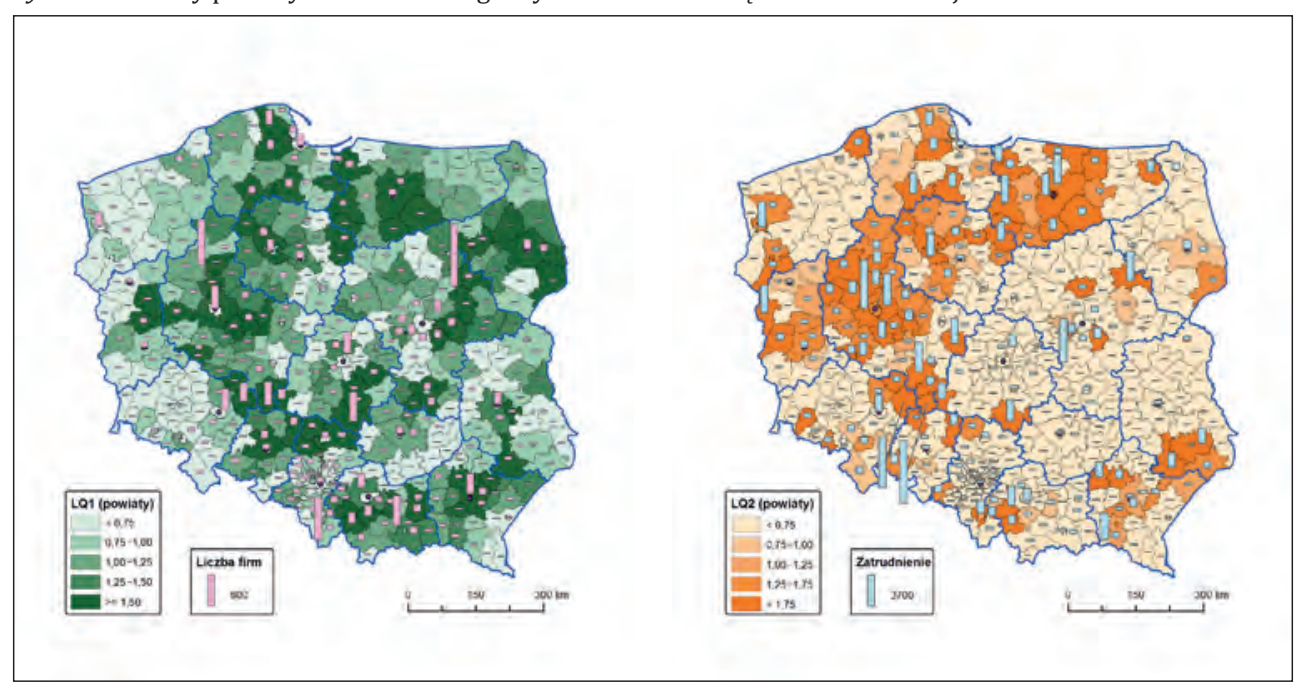

Źródło: opracowanie własne

w odniesieniu do zatrudnienia we wszystkich działach gospodarki ogółem najwyższe wartości dotyczyły województw: wielkopolskiego $(1,51)$, małopolskiego $(1,42)$ i opolskiego $(1,09)$.

Dalsze analizy dotyczyły szczebla subregionalnego - powiatowego (ryc. 6-7). Najwyższe ilorazy lokalizacji dla liczby firm meblarskich (LQ1) obliczone zostały dla powiatów: kępińskiego $(12,08)$, radomszczańskiego $(9,87)$, wadowickiego $(7,85)$, wieruszowskiego $(7,63)$, oleśnickiego $(5,54)$, rzeszowskiego $(5,29)$, elbląskiego $(4,90)$, oleskiego $(4,52)$, suskiego $(4,32)$ i łomżyńskiego $(3,64)$. Największe wartości ilorazów lokalizacji dla zatrudnienia w meblarstwie (LQ2) obliczone zostały dla powiatów: kępińskiego $(26,99)$, słubickiego $(14,28)$, miasta Krosna $(13,94)$, oleśnickiego $(11,66)$, ostrowskiego w Wielkopolsce $(9,73)$, wieruszowskiego $(8,98)$, nidzickiego $(8,23)$, oleckiego $(7,69)$, tureckiego $(7,34)$ i iławskiego $(7,33)$. Zauważyć należy, że w wynikach ilorazu lokalizacji według zatrudnienia zaznaczają się te powiaty, w których znajdują się największe w kraju przedsiębiorstwa meblarskie, zatrudniające ponad 1000 osób, m.in. krośnieński (Grupa Nowy Styl), iławski (GM Szynaka), kępiński (Grupa G3), oleśnicki (FM Bodzio), ostrowski (Com 40. Limited). Wysoko na liście są również m.in. powiat goleniowski (siedziba firmy Ikea), brodnicki (SITS) i poznański (Hilding Anders Polska).

Zastosowana metoda lokalnych związków przestrzennych dla autokorelacji przestrzennej pozwoliła na dokładniejsze wyznaczenie zasięgów klastrów firm meblarskich (ryc. 8-9) oraz zatrudnienia w meblarstwie (ryc. 10-11).

Największe klastry firm meblarskich (liczone zarówno w wartościach bezwzględnych, jak i względnych - przy pomocy ilorazu lokalizacji) wyznaczone zostały dla obszaru na styku województwa wielkopolskiego, dolnośląskiego i łódzkiego, a także zachodniej części województwa małopolskiego, w południowej części aglomeracji warszawskiej oraz wschodniej części aglomeracji poznańskiej.

Jeszcze wyraźniejsze klastry wyznaczone zostały dla zatrudnienia w sektorze meblarstwa. Obszary, w których koncentracja pracowników w sektorze meblarskim jest największa to: styk województwa wielkopolskiego, dolnośląskigo i łódzkiego (powiaty 
Ryc. 8-11. Klastry przemysłu meblarskiego wyznaczone metodą lokalnych związków przestrzennych autokorelacji przestrzennej

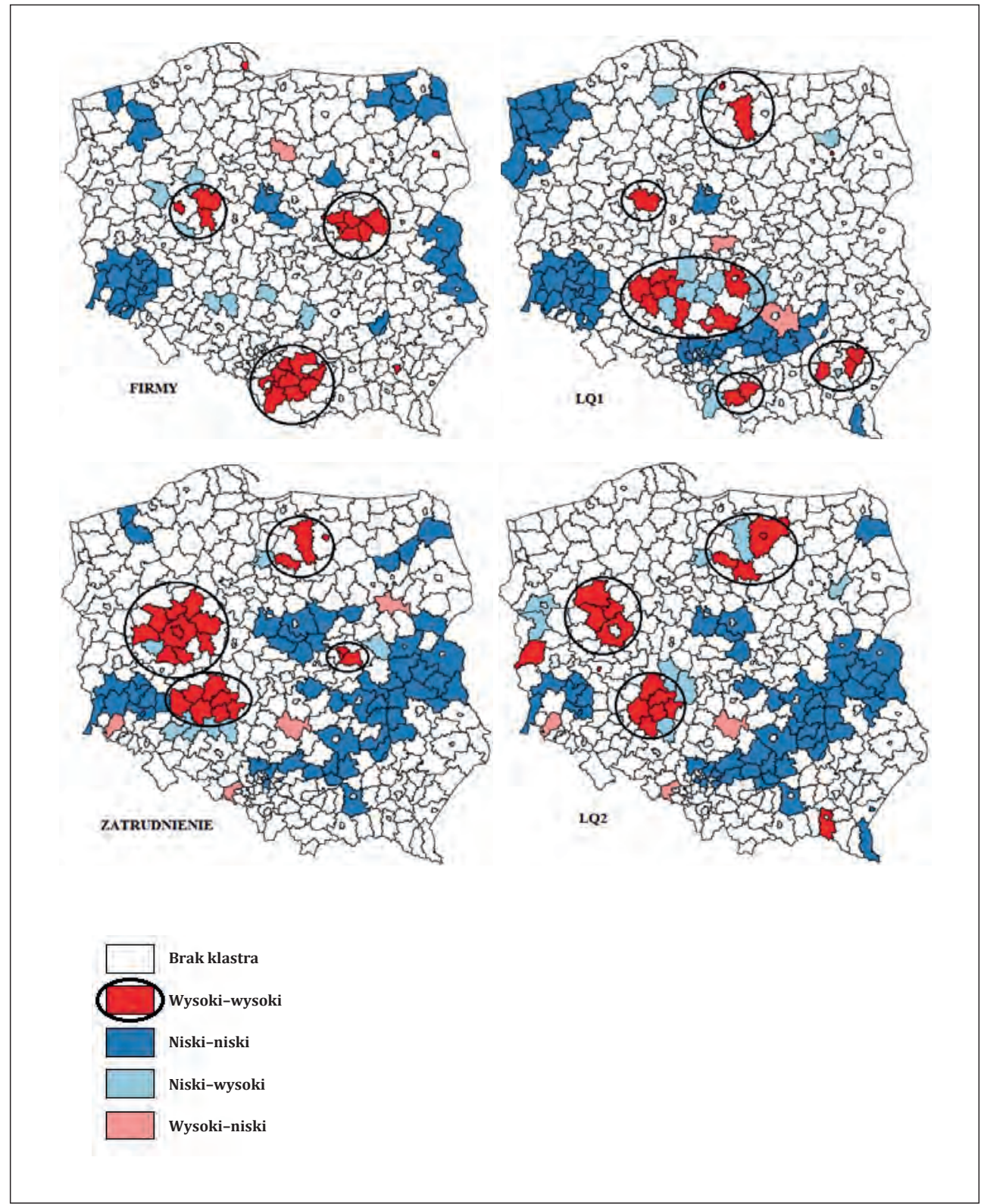

Źródło: opracowanie własne

kępiński, ostrzeszowski, oleśnicki, ostrowski, wieruszowski), aglomeracja poznańska (powiaty m. Poznań i poznański, szamotulski, obornicki, czarnowsko-trzcianecki) oraz zachodnia część województwa warmińsko-mazurskiego (powiat nowomiejski, iławski, ostródzki). W tych klastrach skupionych jest ok. 20\% pracowników w firmach meblarskich w kraju. 


\section{INICJATYWY I ORGANIZACJE KLASTROWE W MEBLARSTWIE W POLSCE}

Analiza źródeł wtórnych: danych PARP, publikacji urzędów marszałkowskich województw, specjalistycznych czasopism i portali internetowych, pozwoliła wykazać, że w ostatnich latach powstało w Polsce 12 inicjatyw i organizacji klastrowych w sektorze meblarstwa. Analiza rozmieszczenia przestrzennego ich siedzib (ryc. 12) wskazuje, że są one zlokalizowane na obszarze siedmiu województw: wielkopolskiego (3), warmińsko-mazurskiego (3), opolskiego (2), lubelskiego (1), kujawsko-pomorskiego (1), zachodniopomorskiego (1) i podlaskiego (1). Zauważyć należy, że są to obszary, w których zidentyfikowane zostały klastry (skupienia, koncentracje) firm meblarskich i zatrudnienia w meblarstwie (np. Klaster Mebel Design w Poznaniu oraz Swarzędzki Klaster Producentów Mebli, Klaster Meblowy Południowej Wielkopolski, Lubawski Klaster Meblowy), oraz obszary o tradycjach meblarskich (Mebel-Elbląg, Dobroteka w Dobrodzieniu), jak i takie miejsca, w których ponadprzeciętna koncentracja firm i zatrudnienia w meblarstwie nie występuje (Zachodniopomorskie Drewno i Meble, Północno-Wchodni Innowacyjny Klaster Drzewny z Suwałk, Stowarzyszenie Lubelskie Drewno). Sugeruje to, że z jednej strony zawiązywaniu takich porozumień przyświeca cel wykorzystania ponadprzeciętnej koncentracji do uzyskania efektu synergii i budowania powiązań pomiędzy firmami i instytucjami meblarskimi; z drugiej - również podmioty związane z produkcją mebli z innych obszarów tworzą formy współpracy dla zaistnienienia (wyróżniania się) w branży i stworzenia możliwości realizacji wspólnych projektów. Jednak w przypadku tych inicjatyw, gdzie liczba firm meblarskich jest niewielka, nazywanie ich „klastrami” jest wysoce dyskusjne. Inicjatywy i organizacje klastrowe to również próba znalezienia przez mniejsze firmy meblarskie swojej niszy rynkowej, pewnego rodzaju opozycja względem firm dużych - zatrudniających powyżej 1000 osób.

Ryc. 12. Inicjatywy i organizacje klastrowe w meblarstwie w Polsce

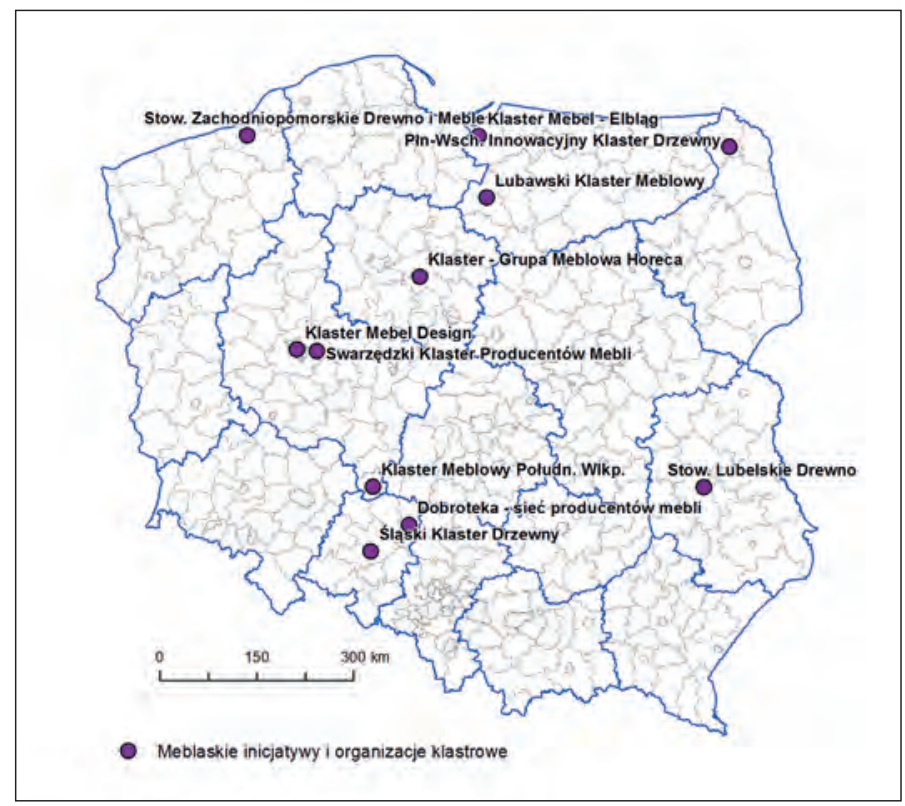

Źródło: opracowanie własne 
Analiza stron internetowych inicjatyw i organizacji klastrowych pozwala stwierdzić, że w każdej z nich zrzeszonych było od kilkunastu do kilkudziesięciu firm, głównie mikro i małych (niekiedy średnich). Łącznie było to ok. 300 firm zatrudniających nie więcej niż 2500 osób, co stanowiło zaledwie niespełna 1\% firm i 1\% zatrudnienia w meblarstwie. Dokładniejsza analiza działań podejmowanych przez porozumienia klastrowe w meblarstwie pokazuje, że tylko niektóre aktywnie wykonują zadania na rzecz swoich członków (np. wspólne działania promocyjne, organizowanie wyjazdów na targi, projekty z instytucjami badawczymi). Ponad połowa w latach 2015-2016 nie podejmowała żadnych działań, a zatem istniała tylko formalnie.

\section{WNIOSKI I DYSKUSJA}

Zaprezentowana $\mathrm{w}$ artykule metoda lokalnych związków przestrzennych jako przestrzennego rozwinięcia autokorelacji przestrzennej okazała się dokładniejszym sposobem identyfikacji klastrów - przestrzennych skupień firm - niż stosowana najczęściej w tym celu w literaturze metoda ilorazu lokalizacji. Przy jej pomocy określone zostały obszary sąsiadujących powiatów, w których występuje wysoka koncentracja liczby firm i zatrudnienia w meblarstwie.

Przeprowadzone badanie pozwoliło zatem potwierdzić, że przemysł meblarski, który odgrywa ważną rolę w polskiej gospodarce, to gałąź, w której firmy i zatrudnienie wykazują wyraźną tendencję do skupiania przestrzennego. Struktura firm meblarskich wskazuje, że w kraju najwięcej jest mikro i małych przedsiębiorstw, w tej kategorii przedsiębiorstw zatrudnionych jest również najwięcej osób. Są one ważne z punktu widzenia społeczeństwa: dają zatrudnienie i zaspokajają potrzeby indywidualnych odbiorów, spełniają indywidualne zamówienia, często na obszarach o gorszej dostępności do sklepów dużych i znanych marek. To jednak duże firmy wpływają na obszary o "nadmiarze" zatrudnienia w meblarstwie w stosunku do zatrudnienia w innych branżach (LQ2), są one także najważniejsze z punktu widzenia kreowania przychodów ze sprzedaży eksportu mebli. Stąd też dla mniejszych firm szansą są inicjatywy i organizacje klastrowe, które jednak jak na razie cieszą się umiarkowaną popularnością wśród firm meblarskich. Sugeruje to, że wciąż aktualne są pojawiające się w niektórych analizach branżowych doniesienia o braku zaufania przedsiębiorców do innych podmiotów (firm, instytucji branżowych) i niechęci do współpracy z nimi oraz preferowaniu działania w pojedynkę.

Należy jednak podkreślić, że przytoczone metody statystyczne i ekonometryczne, oparte na agregacji danych dotyczących firm meblarskich do poziomu jednostek administracyjnych (województw i powiatów), mają ograniczenie w postaci utraty części informacji. Zdaniem niektórych autorów dyskusyjne jest również wykorzystywanie w toku analizy autokorelacji przestrzennej zero-jedynkowej macierzy sąsiedztwa, w której jednostki sąsiadujące mogą mieć długą wspólną granicę albo też sąsiadować na krótkim odcinku (a w skrajnej sytuacji stykać się w jednym punkcie). Należy ponadto pamiętać, że baza danych firm meblarskich, sporządzona na podstawie rejestru REGON (szczególnie w zakresie zatrudnienia), z pewnością jest obarczona pewnym błędem statystycznym (szacunkowo $20-30 \%$ wpisanych tam podmiotów może już nie funkcjonować na rynku). Ograniczeniem przytaczania sformalizowanych inicjatyw i organizacji klastrowych jest fakt, że część z nich już w momencie oddania artykułu do druku jest nieaktywna. 
W dalszych badaniach, dla jeszcze dokładniejszego wyznaczenia granic klastrów meblarskich, warto prowadzić analizy statystyczne również na poziomie gmin oraz traktując firmy meblarskie jako punkty na mapie o określonych współrzędnych geograficznych (tzn. bez agregacji do jednostek terytorialnych, np. powiatów). Wyznaczone opisanymi w artykule metodami klastry meblarskie mogą podlegać w przyszłości różnym badaniom szczegółowym, np. analizie relacji współpracy i przepływów wiedzy lub konkurencji pomiędzy podmiotami, metodom marketingu i budowania wspólnych przewag konkurencyjnych, włączeniu w globalne łańcuchy wartości. Władze samorządów regionalnych i lokalnych, na terenie których znajdują się wyróżnione w artykule klastry meblarskie, powinny uwzględniać ich istnienie w strategiach rozwoju gospodarczego.

\section{Podziękowania}

Autor dziękuje za konsultacje i cenne sugestie prof. Tadeuszowi Stryjakiewiczowi oraz dr. Tomaszowi Kossowskiemu z Instytutu Geografii Społeczno-Ekonomicznej i Gospodarki Przestrzennej w Poznaniu.

\section{Literatura \\ References}

Anselin, L. (1988). Spatial Econometrics: Methods and Models. Dordrecht: Kluwer.

Anselin, L. (1995). Local indicators of Spatial Association-LISA. Geographical Analysis, 27, 93-115. Brodzicki, T., Szultka, R. (2002). Koncepcja klastrów a konkurencyjność przedsiębiorstw. Organizacja i Kierowanie, 4(110), 45-60.

Brodzicki, T., Kuczewska, J. (red.) (2013). Klastry i polityka klastrowa w Polsce: konkurencyjność przedsiębiorstw, sektorów i regionów. Gdańsk: Wydawnictwo Uniwersytetu Gdańskiego.

Cliff, A.D., Ord, J.K. (1973). Spatial autocorrelation. London: Pion.

Cruz, S.C.S., Teixeira, A.A.C. (2010). The Evolution of the Cluster Literature: Shedding Light on the Regional Studies - Regional Science Debate. Regional Studies, 44(9), 1263-1288

Czapliński, P., Rachwał, T., Tobolska, A., Uliszak, R. (2013). Geografia gospodarcza - przewodnik do ćwiczeń. Poznań: Bogucki Wydawnictwo Naukowe.

Dyba, W. (2012). Klasyfikacja rodzajowa i polityka wspierania klastrów gospodarczych w województwie wielkopolskim. Rozwój Regionalny i Polityka Regionalna, 20, 73-86.

Dyba, W. (2016a). Współpraca i przepływy wiedzy w organizacjach klastrowych w świetle polityki klastrowej UE - przykład badania relacji łączących przedsiębiorstwa z wykorzystaniem analizy sieciowej. Prace Komisji Geografii Przemysłu Polskiego Towarzystwa Geograficznego, $30(1), 124-142$.

Dyba, W. (2016b). Knowledge flows in bottom-up and top-down cluster initiatives. Regional Studies, Regional Science, 3(1), 287-295.

Dyba, W., Stryjakiewicz, T. (2014). Inicjatywy klastrowe jako szansa rozwoju przemysłu meblarskiego w Polsce - przykład Swarzędzkiego Klastra Producentów Mebli. Prace Komisji Geografii Przemysłu Polskiego Towarzystwa Geograficznego, 27, 181-196.

Fajferek, A. (1966). Region ekonomiczny i metody analizy regionalnej. Warszawa: Polskie Wydawnictwo Ekonomicne.

Gorynia, M., Jankowska, B. (2008). Klastry a międzynarodowa konkurencyjność i internacjonalizacja przedsiębiorstwa. Warszawa: Wydawnictwo Difin.

Gorynia, M., Jankowska, B., Owczarzak, R. (2007). Clusters - an attempt to respond to the globalisation challenge? The case of furniture cluster in Wielkopolska. Poznań University of Economics Review, 7(2), 5-28.

Isard, W. (1965). Metody analizy regionalnej. Warszawa: Państwowe Wydawnictwo Naukowe, 16-19.

Jędrysiak, A., Piwoni-Krzeszowska, E. (2012). Konkurencyjność klastrów meblarskich w Polsce na tle podobnych inicjatyw w Europie. Nauki o Zarządzaniu, 1(10), 102-116. 
Kalupa, R. (2007). Strategia rozwoju Wielkopolskiego Klastra Meblarskiego. Poznań: Wielkopolska Agencja Rozwoju Przedsiębiorczości.

Kapuściński, M., Koszarek, M., Listwoń, M., Szultka, S. (2007). Strategia rozwoju Zachodniopomorskiego Klastra Drzewno-Meblarskiego. Gdańsk: Instytut Badań nad Gospodarką Rynkową.

Kopczewska, K. (2006). Ekonometria i statystyka przestrzenna z wykorzystaniem programu $R$ CRAN. Warszawa: CeDeWu.

Kossowski, T. (2009). Metody i modele ekonometrii przestrzennej. W: Z. Zwoliński (red.). GIS platforma integracyjna geografii. Poznań: Bogucki Wydawnictwo Naukowe, 145-165.

Kowalski, A.M. (2013). Znaczenie klastrów dla innowacyjności gospodarki w Polsce. Warszawa: Oficyna Wydawnicza Szkoły Głównej Handlowej.

Mackiewicz, M., Kwiatkowski, M., Sętorek, A. (red.) (2015). Drewno i meblarstwo - raport końcowy. Badanie potencjału innowacyjnego i rozwojowego przedsiębiorstw funkcjonujących $w$ obszarze inteligentnych specjalizacji województwa warmińsko-mazurskiego. Warszawa: Geoprofit, Ecorys.

Martin, R., Sunley, P. (2003). Deconstructing clusters: chaotic concept or policy panacea? Journal of Economic Geography, 3(1), 5-35.

Polskie meble - raport branżowy (2016). Biuro ekspertyz banku Pekao S.A. Warszawa.

Porter, M.E. (1990). The competitive advantage of nations. New York: Macmillan.

Rachwał, T. (2010). Struktura przestrzenna i działowa przemysłu Polski na tle Unii Europejskiej w dwudziestolecie rozpoczęcia procesów transformacji systemowej. Prace Komisji Geografii Przemysłu Polskiego Towarzystwa Geograficznego, 16, 106-124.

Ratajczak-Mrozek, M., Herbeć, M. (2013). Active and inactive clusters In Polish furniture industry. The industrial network approach. Intercathedra, 29(3), 85-94.

Skawińska, E., Zalewski, R.I. (2009). Klastry biznesowe w rozwoju konkurencyjności i innowacyjności regionów. Świat - Europa - Polska. Warszawa: Polskie Wydawnictwo Ekonomiczne.

Stryjakiewicz, T. (1999). Adaptacja przestrzenna przemysłu w Polsce $w$ warunkach transformacji systemowej. Poznań: Wydawnictwo Naukowe UAM, 128-131.

Suchecki, B. (red.) (2010). Ekonometria przestrzenna - metody i modele analizy danych przestrzennych. Warszawa: Wydawnictwo C.H. Beck.

Szultka, S., Koszarek, M., Piwowarczyk, D. (red.) (2005). Wstępna analiza trzech potencjalnych klastrów w województwie zachodniopomorskim. Gdańsk: Instytut Badań nad Gospodarką Rynkową.

Troc, M. (1991). Ćwiczenia z geografii przemysłu. Kraków: Wydawnictwo Naukowe WSP.

Artykuł powstał w ramach realizacji grantu NCN nr 2015/17/N/HS4/00205, finansowanego ze środków Narodowego Centrum Nauki.

Wojciech Dyba, dr inż., adiunkt w Instytucie Geografii Społeczno-Ekonomicznej i Gospodarki Przestrzennej Uniwersytetu im. Adama Mickiewicza w Poznaniu. Stypendysta Fundacji UAM, członek Regional Studies Association. Autor dwóch współautorskich monografii naukowych oraz współredaktor jednej pracy zbiorowej, autor lub współautor 14 artykułów lub rozdziałów w monografiach naukowych. W pracy badawczej zajmuje się tematyką klastrów w gospodarce, polityką regionalną oraz strategiami rozwoju regionalnego i lokalnego.

Wojciech Dyba, Ph.D. Eng., assistant in the Institute of Socio-Economic Geography and Spatial Management of Adam Mickiewicz University in Poznan. He is a stipendiary of Adam Mickiewicz Foundation and is a member of Regional Studies Association (Early Career). He is a co-author of two academic monographs and a co-editor of one monograph, the author of 14 articles and chapters in books. In his research he deals with clusters, regional p olicy and strategies for local and regional development.

\section{Adres/address:}

Uniwersytet im. Adama Mickiewicza w Poznaniu Instytut Geografii Społeczno-Ekonomicznej i Gospodarki Przestrzennej ul. Bogumiła Krygowskiego 10, 61-680 Poznań, Polska e-mail:wojtek@amu.edu.pl 